\title{
Phosphorus Dosage and Cow Urine to Chlorophyll and Proline Content on Binucleate Rhizoctonia by Induced Resistance of Vanilla
}

\author{
Haryuni $^{1}$, Endang Suprapti ${ }^{1}$, Tyas Soemarah Kurnia Dewi ${ }^{2}$, Teguh Supriyadi ${ }^{3}$, Azis Andyan \\ Nugroho $^{4}$, Achmadi Priyatmojo ${ }^{5}$, Misri Gozan ${ }^{6}$ \\ ${ }^{1,2,3,4}$ Faculty of Agriculture, Universitas Tunas Pembangunan., Surakarta Central Java, Indonesia; \\ ${ }^{5}$ Faculty of Agriculture, Universitas Gadjah Mada., Yogyakarta Indonesia \\ ${ }^{6}$ Industrial Bioprocess Enginering Resarch Group, Chemical Engineering Department, Faculty of \\ Engineering, Universitas Indonesia. Depok, Indonesia \\ Corresponding email: yuni_utp@yahoo.co.id \& endang.fapertautp@gmail.com
}

\begin{abstract}
Indonesian Vanilla (Vanilla Planifolia) has been export in many countries. The decrease production is caused by decreased plant resistance and increased environmental temperature. This research is to know the effect of phosphorus dosage and cow urin on chlorophyll content and proline of induced resistance of vanilla by Rhizoctonia binucleic (BNR). The study was conducted at Greenhouse Faculty of Agriculture Universitas Tunas Pembangunan Surakarta from March to June 2018. Before planting every seed of vanilla was inoculated with BNR 15g, the design used Randomized Completely Block Design consisted of two factors. The first factors dosage were $6 \mathrm{~g}, 9 \mathrm{~g}$, and $12 \mathrm{~g}(\mathrm{P} 1, \mathrm{P} 2$, and $\mathrm{P} 3)$, second factor dosage of cow urine $0 \mathrm{ml}, 10 \mathrm{ml}$, $20 \mathrm{ml}$, and $30 \mathrm{ml}$ (S0, S1, S2 and S3). Each treatment was repeated 10 times taken 3 plants as sample. The result showed that the treatment dosage of phosphorus and cow urine had significant effect on chlorophyll content and vanilla seed proline. The highest chlorophyll content was $0.28 \%$ (P3S3), and the lowest was $0.10 \%$ (P1S1), the highest prolin content was 2,338 m mol proline / gram (P3S2) and the lowest was $0.64 \mathrm{~m}$ mol proline /gram (P3S1).
\end{abstract}

Key words: Phosphorus, chlorophyll, proline, vanilla.

\section{Introduction}

Indonesian vanilla is a type of commodity originating from the orchidaceae family, the content of vanillin is high, which is $2.75 \%$ [1]. Vanilla development in Indonesia has a promising prospect, but there is some reason that must be spent, namely a truly appropriate business, and maintenance of plants. One form of village maintenance is fertilization. The fertilizer needed by the vanilla plant is phosphorus (P) fertilizer.

One of the most essential nutrients is P. In general, $\mathrm{P}$ in the soil is a limiting factor for crop yields compared to other nutrients. A sufficient amount of $\mathrm{P}$ in the soil encourages plant growth and accelerates the maturity of the seeds and even plays a role in improving the quality of crop yields. $\mathrm{P}$ can strengthen stem growth, increase plant resistance to damage by disease, help move substances from the stem, leaves and other parts of the plant to the seeds. The limitation of $\mathrm{P}$ is one of the main obstacles in increasing agricultural production. Less effective $\mathrm{P}$ fertilizer given to the soil due to the low organic matter contained in the soil. If the organic material contained in the soil is low at $<2 \%$ [2].
One of the organic ingredients that can be used as organic fertilizer is cow urine. The manufacture of liquid organic fertilizer for cow urine is quite easy, cheap, easy to obtain and environmentally friendly [3]. The provision of liquid organic fertilizer is more evenly distributed, directly absorbed by plants, this is because of its solubility. So that quickly overcomes nutrient deficiency and is not problematic in nutrient leaching and easily available to plants [4]. With the use of liquid urine organic fertilizer, it is expected to increase $\mathrm{P}$ in the soil. Availability of $\mathrm{P}$ in plants will affect the proline content of plants. Proline is a biochemical characterizing compound or osmotic metabolite which is widely synthesized and accumulated in various plant tissues, especially on leaves when plants face drought stress [5]. Proline was synthesized through the glutamate pathway through proline-5 carboxylate (P5C) and catalyzed by proline- 5 carboxylase synthetase (P5CS) and proline-5-carboxylase reductase (P5CR) [6].

In addition to affecting the proline content of $\mathrm{P}$ fertilizer application and liquid organic fertilizer, cow urine affects the chlorophyll content of plants. Photosynthesis, which 
occurs in the leaves requires two main ingredients, namely $\mathrm{CO} 2$ and $\mathrm{H} 2 \mathrm{O}$. The main reaction of photosynthesis occurs in chloroplasts with its main agent, chlorophyll. Chlorophyll formation in the leaves is most influenced by sunlight. But the age of the leaves also affects the chlorophyll content contained in a leaf. Whereas at the beginning of leaf development, leaf meristem activity causes the leaf to elongate. The subsequent leaf extension occurs as a result of the activity of intercalary meristems [7].

This research aims to examine the effect of cow's phosphorus and urine doses on chlorophyll and proline by inoculating Binucleic Rhizoctonia (BNR) induce resistance to vanilla. In addition this study is useful for students of biology education study programs in studying plant physiology, especially photosynthesis which affects the formation of chlorophyll and proline plants.

\section{Methods}

This research was conducted in March to June 2018 at the Greenhouse Faculty of Agriculture, Universitas Tunas Pembangunan.
The materials used in this research include: Vanilla seeds which have been inoculated with Binucleate Rhizoctonia (BNR), phosphorus, liquid organic fertilizer, cow urine, water. vegetable pesticides.

The research method used in this study is the basic factorial complete design pattern (CRD). The first factor is the variation of phosphorus fertilizer dosage: $6 \mathrm{~g} / \mathrm{plant}, 9$ g/plant, $12 \mathrm{~g} /$ plant (named as P1, P2, and P3), the second factor is the dose of liquid urine organic fertilizer: $10 \mathrm{ml} /$ plant, $20 \mathrm{ml} /$ plant, 30 $\mathrm{ml} / \mathrm{plant}$. (named as $\mathrm{S} 1, \mathrm{~S} 2$, and $\mathrm{S}$ ) there are 12 treatment combinations. Each treatment was repeated 10 times, 3 plants were taken as observation samples. Parameters in this research include the chlorophyll content with the Kjedahl method [8] and the content of proline by method [9] and the content of the data obtained from the observations were analyzed by analysis diversity with a level of $5 \%$. If it is significantly different then proceed with Duncan's Multiple Range Test (DMRT) to distinguish treatment.

\section{Results and Discussion}

\subsection{Chlorophyll contents}

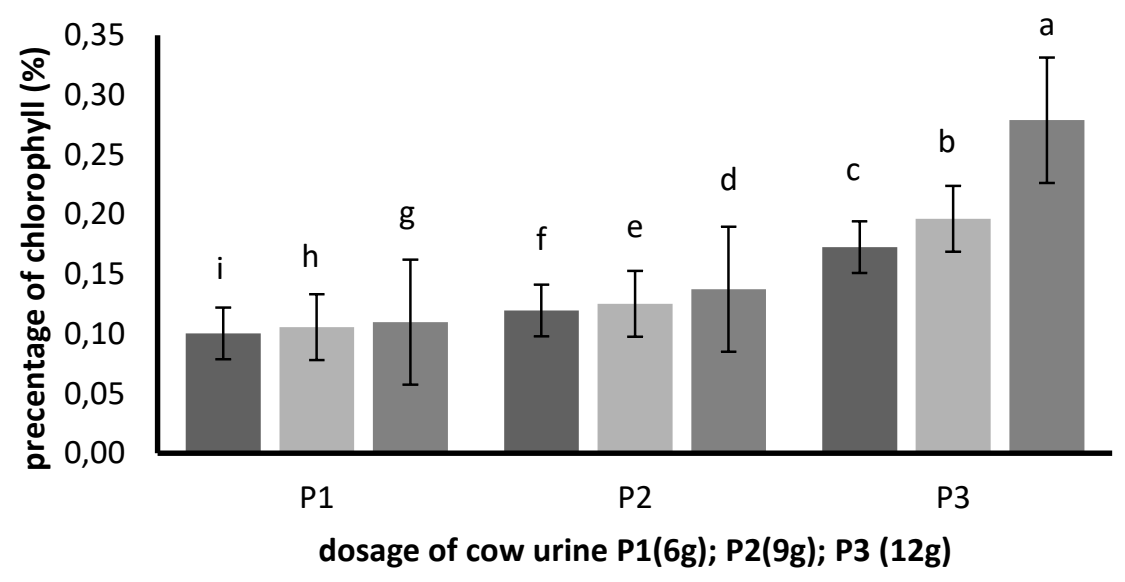

$\square$ S1 $\square$ S2 $\square 3$

Figure 1. Graph of the effect of $P$ fertilizer and liquid urine organic fertilizer on the percentage of chlorophyll content in vanilla plants.

Figure 1 shows the interaction of giving phosphorus fertilizer and liquid organic fertilizer for cow urine affecting the chlorophyll content of vanilla plants. the highest chlorophyll content in the treatment of $12 \mathrm{~g} /$ plant $\mathrm{P}$ fertilizer and $30 \mathrm{ml} /$ plant
(P3S3) cow urine liquid organic fertilizer with chlorophyll content of $0.84 \%$. The lowest chlorophyll content in the combination treatment P1S1 is the dose of phosphorus fertilizer $6 \mathrm{~g} /$ plant and liquid organic fertilizer $10 \mathrm{ml} /$ plant with chlorophyll content of 
$0.30 \%$. Phosphorus fertilizer is very influential on chlorophyll content in plants, this is supported by research conducted by [10] on oil palm plants giving linear $\mathrm{P}$ fertilizer increases chlorophyll content. Supported by [11] an increase in $\mathrm{P}$ increases the content of chlorophyll plants.

\subsection{Proline contents}

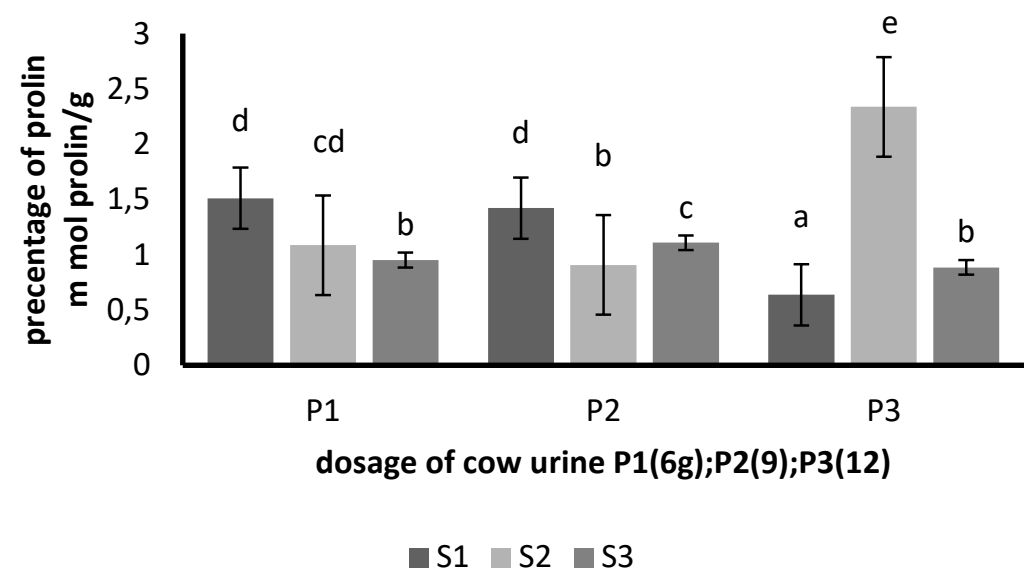

Figure 2. Graph of the effect of $\mathrm{P}$ fertilizer and liquid urine organic fertilizer on the percentage of proline content in vanilla plants.

Figure 2 shows that $\mathrm{P}$ fertilizer and liquid organic fertilizer affect the proline content of vanilla plants. The highest proline content in the combination of $12 \mathrm{~g} /$ plant phosphorus fertilizer treatment and cow urine liquid organic fertilizer was $20 \mathrm{ml} /$ plant (P3S2) with proline content of 7,014 m mol proline / g. The lowest proline content in P3S1 treatment is the dose of phosphorus $6 \mathrm{~g}$ fertilizer and liquid organic fertilizer $10 \mathrm{ml}$ urine / plant with proline content $1.92 \mathrm{~m}$ mol proline / g. It is suspected that the treatment of $\mathrm{P}$ fertilizer on vanilla plants interacting with mycorrhizae given at the time of nursery can increase the growth of vanilla root plants. Increased root growth can support absorption of nutrients and water in the soil. [12] who explained that mycorrhizal infection in vanilla flow showed symbiosis between plants and mycorrhizae. Advantages of mycorrhizal association with plants because mycorrhizae are effective in conditions that are less favorable for plants such as low soil fertility and limited water availability. Provision of organic fertilizer for liquid cow urine can improve soil structure and increase groundwater binding capacity. According to [13] the provision of organic fertilizer improves soil structure, in sandy soils increases the binding capacity of groundwater, while in clay the water binding capacity is high, the binding capacity of the soil for nutrients increases and drainage and AC soil can be increased. Storing water on the ground through the provision of liquid organic fertilizer will reduce the stress of plant drought.

\section{Conclusion}

The dose of phosphorus treatment and cow urine has a significant effect on the chlorophyll content and proline of vanilla seeds. The highest chlorophyll content was $0.28 \%$ (P3S3), and the lowest was $0.10 \%$ (P1S1), the highest proline content was $2.34 \mathrm{~m}$ mol proline / gram (P3S2) and the lowest was $0.64 \mathrm{~m}$ mol proline / gram (P3S1).

\section{References}

Erona,S. Meisilva. 2016. Growth of Vanilla (Vanilla planifolia Andrews) Inoculations with Arbuscular Mycorrhyzal Fungi and Trichoderma harzianum at Ultisol. Sekolah Pasca Sarjana Institut Pertanian Bogor. https://www.repository.ipb.ac.id 43p.

Sumarni,T.,S. Fajriani, O.W. Effendi. 2012. The response of soybean crops on phosphorus fertilizer and Mexican sunflower green manure application. Prosiding Seminar Hasil Penelitian Tanaman Aneka Kacang dan Umbi. 
Fakultas Pertanian Universitas Brawijaya.

https://www.balitkabi.litbang.pertanian. go.id. 183-189

Sholikhin,R., A. Khoiri, M. Nurbaiti. 2014. Application Of Cow Urine On The Growth And Yield Mustard (Brassica Juncea L.). https://media.neliti.com. 7p.

Priangga R., Suwarno dan Hidayat N. 2013. The Level Effect Of Liquid Organic Fertilizer :Their Effects On Dry Matter Production And Leaf To Stem Ratio Of Elephant Grass At ${ }^{4}$ Nd Defoliation. Jurnal Ilmiah Peternakan 1(1): 365-373. https://www.download.portalgaruda.org

Hamim, K. Ashri, Miftahudin, dan Triadiati. 2008. Response of Rubber Clones to requency of Watering in Sand Tailings Media Derived from Tin Post-Mining. Agrivita 30 (30) : $201-210$.

Raymond, M.J. and N. Smirnoff. 2002. Proline Metabolism and Transport in Maize Seedling at Low Water Potensial. Ann. Bot . $89: 813-823$.

Hidayat. Nurul. 2008. Pertumbuhan dan Produksi Kacang Tanah (Arachis hypogea. L) Varietas Lokal Madura Pada Berbagai Jarak Tanam dan Dosis Pupuk Fosfor. Journal Trunojoyo.ac.id 1(1): 55-64.

Peni. D.K., I, Solichatun., E. Anggarwulan (2004) Growth, content of chrorophyll- carotenoids, saponins, and activity of nitrate reductase of Acalypha (Acalyphaindica L.) under different tea concentrations of gibberelic acid (GA3). Biopharmaceutical 2 (1): 1-8.

Daryanti. Haryuni. Dwi Susilo Utami. 2014. Effect of Rhizoctonia Bunucleate Resistance to water in seedlings of vanilla (Vanilla planifolia Andrews). Agrineca 14 (1): 47-62.

Shintarika,Feni., Sudradjat, Supijatno. 2015 Optimizing of Nitrogen and Phosphorus fertilizer for One-Year-Old Plant of Oil Palm (Elaeis guineensis Jacq.) J.Agron.Indonesia 43 (3):250- 256.

Haryuni. Tyas Soemarah Kurnia Dewi. 2016. The Effects of Dose Rhizoctonia Binucleat (BNR) and Phosphorus to Nitrate Reductase Activity (NRA) and Chlorophyll of Vanilla Seedling (Vanilla planifolia Andrews). Biosaintifika 8 (2): 141-147.

Tirta, I. G. 2006. The effect of potassium and mycorrhiza on growth of vanilla (Vanilla planifolia Andrew) Biodiversitas 7 (2) 2006. 171-174.

Rosniawaty, S., R. Sudirja dan H. Afrianto. 2015. Utilizing of rabbit and cow urine as organic fertilizer liqiud alternative on cocoa (Theobroma cacao L.) Jurnal Kultivasi. $14 \quad$ (1): $32-36$. https://www.jurnal.unpad.ac.id 